\title{
Factors Influencing the Adoption and Utilization of Selected Agricultural Technologies by Cotton Farmers in Zimbabwe
}

\author{
Washington Muzari \\ Senior Lecturer, Department of Agricultural Engineering, Chinhoyi University of Technology, P. Bag 7724, Chinhoyi, Zimbabwe
}

\begin{abstract}
A multi-pronged survey of secondary literature was adopted. Journal papers, institutional publications, research reports, conference proceedings, and internet websites were consulted in gathering data for this study. It is believed that low rates of technological uptake and the failure by farmers to realize productivity increases are chiefly a result of inappropriate agricultural extension models. Despite the declining world demand and falling international prices of cotton, cotton is nevertheless still an important crop for employment creation and foreign currency generation in Zimbabwe. Thus its production should continue to receive technical, institutional, fiscal and financial support in Zimbabwe. Income from cotton sales is used to finance household expenditures, particularly in the major cotton producing belts of the country. However, unsustainable cultivation methods and inappropriate land husbandry practices by cotton farmers have led to extensive land degradation and depletion of soils. Other constraints militating against the viability of smallholder cotton farming include high cost of variable inputs such as pesticides and soil fertility amendments (fertilizers), the incidence of pests and diseases, frequent and devastating droughts, and lack of price incentives for cotton producers. Two recent innovations for reducing land degradation, eliminating pest damage, increasing agricultural productivity, enhancing environmental sustainability, and improving human health, are conservation tillage and integrated production and pest management. Some of the factors which influence the adoption of cotton technologies include user awareness, education level of the farmer, access to extension services, availability of labour and animal draft power. Policy efforts should therefore aim at intensifying the use of farmer field schools, raising education levels in the rural areas, increasing the extension worker-to-farmer ratios in cotton producing areas, more emphasis on labour-saving components of these technologies, and cattle restocking exercises to promote draft power availability among smallholders.
\end{abstract}

Keywords: cotton, adoption, technologies, innovations, conservation agriculture, pest management

\section{Introduction}

Agriculture is pivotal to Zimbabwe's economic development. From the attainment of independence in 1980 to 1994 , agriculture was contributing between $15-20 \%$ of the country's Gross Domestic Product (GDP) (Rukuni and Eicher, 1994). However, agricultural GDP had declined to $10 \%$ after the year 2000 because of the changes taking place under Zimbabwe's land reform programme (FAO, 2001).

A series of agricultural technologies have been implemented with the aim of improving productivity in agriculture in Africa south of the Sahara. Generally, however, farmers have been slow to respond in taking up and utilizing these innovations (Mutandwa and Mpangwa, 2004). It is believed that low rates of technological uptake and the failure by farmers to realize productivity increases are chiefly a result of inappropriate agricultural extension models.

In Zimbabwe, cotton is ranked second after tobacco in terms of its importance on the export market. This is despite the fact that the cotton sub-sector is fraught with difficulties arising from international competition and worsening world prices (USDA, 2012). These two crops have in the past always contributed significantly in reducing the rate of unemployment and generating the much needed foreign exchange (Mutandwa and Mpangwa, 2004). However, the proliferation of anti-smoking lobbies globally has made it imperative for the country to seek other alternatives to tobacco in generating agricultural export earnings. Hence the renewed focus and emphasis on the horticultural and cotton sub-sectors in Zimbabwe as non-tobacco foreign currency earners. But horticultural production is beyond the reach of the majority of smallholder farmers because it requires huge doses of capital which the small farmers are unable to mobilize. Therefore despite the declining world demand and falling international prices of cotton, these factors have weighed heavily in favour of cotton being an important crop whose production should continue to receive technical, institutional, fiscal and financial support in Zimbabwe.

The bulk of the cotton crop in Zimbabwe originates from the smallholder sector (Mavunganidze et al., 2013). Income from cotton sales is used to finance household expenditures, particularly in the major cotton producing belts of the country. However, unsustainable cultivation methods and inappropriate land husbandry practices by cotton farmers have led to extensive land degradation and depletion of soils (Gwenzi et al., 2009). Other constraints militating against the viability of smallholder cotton farming include high cost of variable inputs such as pesticides and soil fertility amendments (fertilizers), the incidence of pests and diseases, frequent and devastating droughts, and lack of price incentives for cotton producers (Mutandwa and Mpangwa, 2004; Mudimu et al., 1995).

\section{Conservation Agriculture}

A scientifically proven antidote to land degradation in cotton production areas and other marginal areas in Zimbabwe is conservation agriculture (Thierfelder and Wall, 2011). The main principles of conservation agriculture are three-fold. Firstly, there should be as little interference with the physical status of the soil as possible in preparing the land 


\section{International Journal of Science and Research (IJSR) \\ ISSN (Online): 2319-7064 \\ Index Copernicus Value (2013): 6.14 | Impact Factor (2014): 5.611}

for planting. Secondly, mulching should cover at least 30\% of the soil surface to minimize soil and moisture losses. Lastly, crops should be grown in rotation over a given piece of land (Kassam et al., 2009; FAO, 2012).

The experimentation, implementation and propagation of conservation agriculture in Zimbabwe dates as far back as 2004 (Mazvimavi and Twomlow, 2009). The principal objective of conservation farming has been to improve agricultural productivity among smallholders (Mazvimavi and Twomlow, 2009). A concurrent objective of conservation agriculture is to reduce land degradation from unsustainable farming practices. However, farmer technological uptake and utilization has progressed at a slow pace and adoption rates have not been as encouraging as originally anticipated (Maunganidze et al., 2013).

\section{Integrated Production and Pest Management and Farmer Field Schools}

In other countries, Integrated Production and Pest Management (IPPM) is known simply as Integrated Pest Management (IPM). It has its origins in Indonesia where it was first implemented among rice farmers (Mutandwa and Mpangwa, 2004). In that country, results of the implementation of IPM were encouraging. The decrease in the use of pesticides was coupled with productivity increases among rice farmers. The additional component of IPPM in Zimbabwe is the incorporation of crop management strategies to enhance crop yields. It was first promoted in Zimbabwe by the FAO Global Facility in conjunction with the Ministry of Agriculture, which implemented a series of pilot projects (IPPM Report, 1999). Two factors that militated against initial success of the pilot phase were the lure of material benefits by farmers, and a general lack of skills among the farmers (Kujeke, 1993).

Therefore, to increase the rate of adoption and technological uptake of IPPM practices, Farmer Field Schools have been introduced in Zimbabwe. The distinctive features of Farmer Field Schools (FFS) are its participatory nature, and farmers learn from experience. It emphasizes farmer empowerment through participatory technology development and transfer. Farmer Field Schools also incorporate indigenous knowledge systems and experience (Nyambo and Kimani, 1998). Thus they offer a useful platform through which farmers, researchers and extension workers can interact and share ideas about IPPM. Unlike single item innovations such as high yielding varieties, IPPM has several components including pest management, soil and water conservation, and weather forecasts.

In Zimbabwe and much of Africa, the menace of insect pest damage among smallholder cotton producers has up to now been dealt with through the application of chemical fertilizers (Maumbe and Swinton, 2000; Adesina, 1994; Ajayi, 1994). But chemical pesticide application offers only a very temporary and short-term solution to pest problems. In addition, pesticides result in pest outbreaks that were not imminent initially. Furthermore, some insect pests may develop a physiological resistance to the functioning of pesticides. Natural predators of insect pests, which assisted in decimating pest populations, may also be wiped out by the destructive effects of chemical pesticides (Burrow, 1983; World Bank, 1997). Besides, pest control in its traditional forms has hitherto not made any provisions for improvements in agricultural productivity, environmental sustainability, and human health. The proponents of integrated production and pest management hold it that IPPM has the crucial role of filling in these important economic, environmental and social benefit gaps (Van deman et al., 1994). Several studies to this effect have been carried out in the developed world (Fernandez-Cornejo, 1998); Swinton et al., 1999; Norton and Mullen, 1993) and South America (e.g. Antle et al., 1998). But a few such studies have focused on Africa (e.g. Maumbe and Swinton, 2000). On the contrary, the undesirable effects of heavy and excessive pesticide applications have also been adequately documented elsewhere (Cole et al., 1998; Loewenson and Nhachi, 1996).

\section{Some Research Findings on Cotton Technologies}

Several studies have been conducted in Zimbabwe on the adoption and efficacy of agricultural extension technologies such as IPPM and conservation agriculture. Studies have also been conducted to evaluate participatory extension methodologies such as Farmer Field Schools. Such studies include those conducted by Mazvimavi and Twomlow (2009), Maunganidze et al. (2013), Maumbe and Swinton (2000), and Mutandwa and Mpangwa (2004).

Mazvimavi and Twomlow (2009) collected data from 232 households in 12 districts to investigate factors that determine technological uptake and adoption of conservation farming among smallholder farmers in Zimbabwe. Results of the survey showed that the most important variables affecting adoption rates were the location of the household in terms of climate and soils, and access to institutional support (Mazvimavi and Twomlow, 2009).

Maunganidze et al. (2013) also conducted a study to identify factors that influence the level of adoption of the various components of conservation agriculture among smallholder cotton growers in Kadoma District of Zimbabwe. Results of the survey showed that farmers do not just blindly accept and adopt the full package of conservation practices availed to them. Rather, they carefully consider and analyze each component on a case by case basis, evaluate its usefulness in terms of relevance to local conditions, perceived benefits, and resource availability, and adopt only those components which they consider as the most useful. Survey results showed that the components of conservation agriculture adopted depended on the farmer's formal education, access to extension services, labour and animal draft power availability. The higher the level of education, and the better the farmer's access to extension services, labour and draft power, the greater the intensity and rate of adoption of conservation agriculture among smallholder cotton growers. The age of the farmer was also a significant factor determing the intensity and rate of adoption, with younger farmers readily adopting more components and at a greater frequency than older farmers (Maunganidze et al., 2013). 


\section{International Journal of Science and Research (IJSR) \\ ISSN (Online): 2319-7064}

Index Copernicus Value (2013): 6.14 | Impact Factor (2014): 5.611

Maumbe and Swinton (2000) estimated an empirical model of IPPM adoption among smallholder cotton growers in the Sanyati District of Zimbabwe. The most striking result in the Poisson regression model was the technological awareness coefficient that was significant at the one percent level. Farmers exposed to the cotton-IPPM techniques through the Farmer Field Schools, were more likely to use several IPPM related practices in cotton pest management. Results also indicated that cotton farmers with larger land sizes under cotton were more likely to have easier access to technical information, thus more likely to implement more IPPM practices in reducing cotton pest damage. Contrary to expectations, the pesticide health risk variables were not significant in the analysis. The lack of statistical significance associated with health risk variables did not support the hypothesis that IPPM adoption decisions are based on pesticide-related health risks. In short, the results of the analysis showed that farmer awareness of Integrated Production and Pest Management practices is significantly associated with their adoption.

Mutandwa and Mpangwa (2004) conducted another study, also in the Sanyati area, to evaluate the impact of farmer field schools in propagating IPPM practices. The study used stochastic efficiency analysis, regression models, technical knowledge scores and gross margin analysis in the evaluation process. These parameters were used as indicators of the effectiveness of the FFS extension approach. Structured interviews, key informants and focus group discussions were employed to collect data for the 2001/02 and 2002/03 seasons. The results of the survey indicated that crop yields, cotton income and technical knowledge scores for participants were greater than for nonparticipants in the IPPM project. It was also shown that technical knowledge was a significant variable in explaining cotton income variance. Therefore, farmer field schools can be considered as an extension option for small cotton farmers because of their participatory nature. However, more needs to be done to appraise their sustainability within the context of land and agrarian reforms in Zimbabwe.

\section{Conclusions}

The preceding discussions and analyses seem to support the conclusion that Integrated Production and Pest Management (IPPM) is a viable option to lift the resource-poor smallholder cotton farmers out of poverty. This it achieves by reducing crop pest damage, lowering variable production costs, raising the levels of agricultural productivity, and ultimately increasing the gross margins of cotton enterprises. Conservation agriculture also works to increase the productivity and sustainability of smallholder agriculture. Farmer field schools are an effective vehicle for propagating or spreading extension messages such as IPPM and conservation agriculture. Because of its participatory and bottom-up characteristics, the farmer field school approach is an effective platform for the interaction of all stakeholders, namely farmers, extension workers and researchers. Some of the factors which influence the adoption of cotton technologies include user awareness, education level of the farmer, access to extension services, availability of labour and animal draft power. Policy efforts should therefore aim at intensifying the use of farmer field schools, raising education levels in the rural areas, increasing the extension worker-to-farmer ratios in cotton producing areas, more emphasis on labour-saving components of these technologies, and cattle restocking exercises to promote draft power availability among smallholders.

\section{References}

[1] Adesina, A.A. (1994). Pesticide Use and Policy in West Africa: An Overview. In: Proceedings of the Gottingen Workshop on Pesticide Policies. Gottingen, Germany. Edited by S. Agne, G. Fleischer and H. Waibal, 28 February - 4 March 1994).

[2] Ajayi, O. (1994). Measuring the Indirect Health Benefits of IPM: Methodology for Estimating Pesticide Health Costs in Africa. Paper presented at the International Workshop on "Evaluation of IPM Programs: Towards a Framework for Economic Evaluation", Garbsen, Hanover, Germany, 25-27 May 1994.

[3] Antle, J.M., Cole, D.C. and Crissman, C.C. (1998). The Role of Pesticides in Farm Productivity and Farmer Health. In: Economic, Environmental and Health Trade-offs in Agriculture: Pesticides and the Sustainability of Andean Potato Production. Edited by C.C. Crissman.

[4] Burrow, M. (1983). Pesticide Demand and Integrated Pest Management: A Limited Dependent Variable Analysis. American Journal of Agricultural Economics, 65,4:806-810, 1983.

[5] Cole, D.C., Carpio, F., Julian, J.A., and Leon, N. (1998). Health Impacts of Pesticide use in Carchi Farm Populations. Kluwer Academic Publishers, 1998.

[6] FAO (2001). FAO/WFP Crop and Food Supply Assessment Mission to Zimbabwe. FAO Global Information and Early Warning System on Food and Agriculture, WFP, 1 June 2001.

[7] FAO (2012). Conservation Agriculture Website. (Available online http:/www.org.ag.ca).

[8] Fernandez-Cornejo, J. (1998). Environmental and Economic Consequences of Technology Adoption: IPM in Viticulture. Journal of Agricultural Economics, 18 (145-155), 1998.

[9] Gwenzi, W., Gotosa, J., Chakanetsa, S., and Mutema, Z. (2009). Effects of tillage systems on soil organic carbon dynamics, structural stability and crop yields in irrigated wheat-cotton rotation in semi-arid Zimbabwe. Nutrient Cycle Agroecosystems 83: 211-221.

[10] IPPM Report, 1999. Integrated Production and Pest Management: A Pilot Project in Zimbabwe. Ministry of Agriculture/ FAO Global Facility.

[11] Kassam, A., Frederich, T., Sharxson, F. and Pretty, J. (2009). The spread of conservation agriculture: justification, sustainability and uptake. Journal of Agriculture and Sustainability 7: 292-320.

[12] Kujeke, T. (1993). Institutions Affecting Integrated Pest Management Use at User Level. In: Pesicide Policies in Zimbabwe: Status and Implications for Change. Pesticide Policy Project, University of Hanover, Germany.

[13] Loewenson, R. and Nhachi, C.F.B. (1996). Epidemiology of health impacts of pesticide use in 


\section{International Journal of Science and Research (IJSR) \\ ISSN (Online): 2319-7064}

Index Copernicus Value (2013): 6.14 | Impact Factor (2014): 5.611

Zimbabwe: Toxicity and Health Implications. Edited by C.F.B. Nhachi and O.M. Kasilo. University of Zimbabwe.

[14] Maumbe, B.M. and Swinton, S.M. (2000). Why Do Cotton Farmers in Zimbabwe Adopt IPM? The Role of Pesticie-Related Health Risks and Technology Awareness. Journal of Sustainable Development in Africa/ Michigan State University.

[15] Maunganidze, Z., Madakadze, I.C., Mutenje, M.J. and Nyamangara, J. (2013). Factors affecting the choice of conservation agriculture practices adopted by smallholder cotton farmers in Zimbabwe. African Journal of Agricultural Research Vol. 8, Issue 17.

[16] Mazvimavi, K. and Twomlow, S. (2009). Socioeconomic and institutional factors influencing adoption of conservation farming by vulnerable households in Zimbabwe. Agricultural Systems.

[17] Mudimu, G.D., Chigume, S. and Chikanda, M. (1995). Pesticide Use and Policies in Zimbabwe - Current Perspectives and Emerging Issues for Research. Pesticide Policy Publications, No. 2, University of Hanover, Germany.

[18] Mutandwa, E. and Mpangwa, J. (2014). An Assessment of the Impact of Farmer Field Schools on Integrated Pest Management Dissemination and Use: Evidence from Smallholder Cotton Farmers in the Lowveld Area of Zimbabwe. Journal of Sustainable Development in Africa.

[19] Norton, G.W. and Mullen, J.D. (1993). Economic Evaluation of Integrated Pest Management Programs. Publication No. 446140, Virginia Polytechnic Institute and State University, Blacksburg, USA, 1993.

[20] Nyambo, B. and Kimani, T. (1998). The Role of Farmer Field Schools: Experiences in Kenya. Proceedings of the IPM Communications Workshop: Eastern and Southern Africa, March 1-6 1998, Nairobi, Kenya. International Center for Insect Physiology and Ecology (ICIPE)

[21] Rola, A.C. and Pingali, P.L. (1993). Pesticides, Rice Productivity and Farmers' Health: An Economic Assessment. World Resources and International Rice Research Institute.

[22] Rukuni, M. and Eicher, C. (1994). Zimbabwe's Agricultural Revolution. University of Zimbabwe Publications.

[23] Swinton, S.M., Owens, N.N., and Ravensway, E.O. (1999). Health Risk Information to Reduce Water Pollution. In Flexible Incentives for the Adoption of Environmental Technologies in Agriculture. Edited by F. Casey et al., pages 263-271.

[24] Thierfelder, C. and Wall, P.C. (2011). Reducing the risk of crop failure for smallholder farmers in Africa through the adoption of conservation agriculture. Springer Science and Business Media. B.V.

[25] USDA (2012). Global Agricultural Information Network. Gain Report.

[26] Van deman, A., Cornejo, J.F., Jans, S., and Lin, B.H. (1994). Adoption of Integrated Pest Management in US Agriculture. United States Department of Agriculture. Economic Research Service. Agriculture Information Bulletin No. 707, Washington, DC.

[27] World Bank (1997). Integrated Pest Management: Strategies and Policies for Effective Implementation.
Environmentally Sustainable Development Studies and Monographs Series No. 13. Washington, DC. 